\title{
Problems of modeling the valuation of residential properties
}

\author{
Tatiana K. Bogdanova ${ }^{\mathrm{a}}$
}

E-ail: tanbog@hse.ru

\author{
Albina R. Kamalova ${ }^{a}$ \\ E-mail: akamalova@hse.ru
}

\section{Tatiana K. Kravchenko ${ }^{a}$}

E-mail: tkravchenko@hse.ru

\section{Anastasia I. Poltorak ${ }^{b}$}

E-mail: poltoraknastya@gmail.com

\author{
${ }^{a}$ National Research University Higher School of Economics \\ Address: 20, Myasnitskaya Street, Moscow 101000, Russia \\ ${ }^{\mathrm{b}}$ Seldon 2 LLC \\ Address: 24 build. 1, Radio Street, Moscow 105005, Russia
}

\begin{abstract}
The solution of the housing problem for many decades has been and remains one of the most important tasks facing the nation. The problem of modeling the value of residential properties is becoming more and more urgent, since a high-quality forecast makes it possible to reduce risks, both for government bodies and for realtors specializing in the purchase and sale of residential properties, as well as for ordinary citizens who buy or sell apartments. Predictive models allow us to get an adequate assessment of both the current and future situation on the residential property market, to identify trends in the cost of housing and the factors influencing these changes. This involves both the qualitative characteristics of the particular property, and the general condition and the dynamics of the real estate market. Russia is characterized by significant differences in the level of development of regions, therefore, by differences in trends of supply and demand prices for real estate. Valuation of residential properties at the regional level is particularly important, since all of the above determines the social and economic importance of this problem. This article presents a comprehensive model for estimating the value of residential properties in the secondary housing market of Moscow using decision tree methods and ordinal logistic regression. A predictive model of the level of housing comfort was built using the CRT decision tree method. The results of this forecast are used as input information for an ordinal logistic regression model for estimating the value of residential properties in the secondary market of Moscow. Testing the model on real data showed the high predictive ability of the model we generated.
\end{abstract}


Key words: model; value estimation; residential properties; secondary housing market; ordinal logistic regression; decision tree; CRT method; value forecast.

Citation: Bogdanova T.K., Kamalova A.R., Kravchenko T.K., Poltorak A.I. (2020) Problems of modeling the valuation of residential properties. Business Informatics, vol. 14, no 3, pp. 7-23.

DOI: $10.17323 / 2587-814 X .2020 .3 .7 .23$

\section{Introduction}

$\mathrm{T}$ The residential property market plays an important role in the development of the social and economic spheres of the country. An unfavorable situation on the real estate market may lead to crises such as the subprime crisis in 2008, when there was a "collapse" in the real estate market due to the sharp increase in delinquencies / defaults on mortgages and mass alienation of property for the benefit of creditors.

According to paragraph 1 of Article 16 of the Housing Code of the Russian Federation, residential properties include: a residential building, a part of a residential building, an apartment, a part of an apartment, a room [1]. At the same time, the residential property market can be conditionally divided into the primary and secondary housing market. The primary market is real estate that appears on the market as a commodity for the first time, and that was not previously owned by someone. The secondary market is real estate that was already used and was in private or municipal ownership. It is important to note that the primary and secondary markets are inextricably linked, since an increase in supply in the secondary market inevitably causes a decline in demand and, consequently, decline in prices in the primary market. If construction costs rise, then prices for residential properties in the primary market, which determine the volume of real estate created, will also rise. In turn, this will lead to an increase in prices in the secondary housing market. The residential property market has low price elasticity.
In the primary property market, property is sold directly by developers or agents. At the same time, it is possible to purchase at different stages of construction, including by agreement on a cost-sharing arrangement. In the secondary market, the buyer always buys a completed apartment. The market value of a real estate property depends on various factors, such as external factors (changes in the procedure for obtaining a building permit, the key rate, conditions for mortgage lending, limitations on price increases, tax incentives, licensing of developers and agents, the economic situation in the country / region, demand for housing etc.) and internal factors (the residential property's surface area, number of rooms, wall material, floor, state of repair, balcony, parking, distance from transport, metro, distance to the city center, etc.).

Experts (appraisers) for real estate valuations in practice mainly use traditional methods: the comparative method, the cost method and the income method. In general, the estimates obtained by these methods may vary. In addition, in most cases a limited set of factors is taken into account, and the final price of a given property is ultimately determined by an expert who is guided by his own experience, the current situation in the real estate market, and available information on the impact of macroeconomic and demographic factors. However, the determination of the objective value of real estate is necessary in a variety of cases: for the purposes of purchase and sale, for tax purposes, for mortgage lending when transferring property as collateral and setting the loan amount by banks, when considering property 


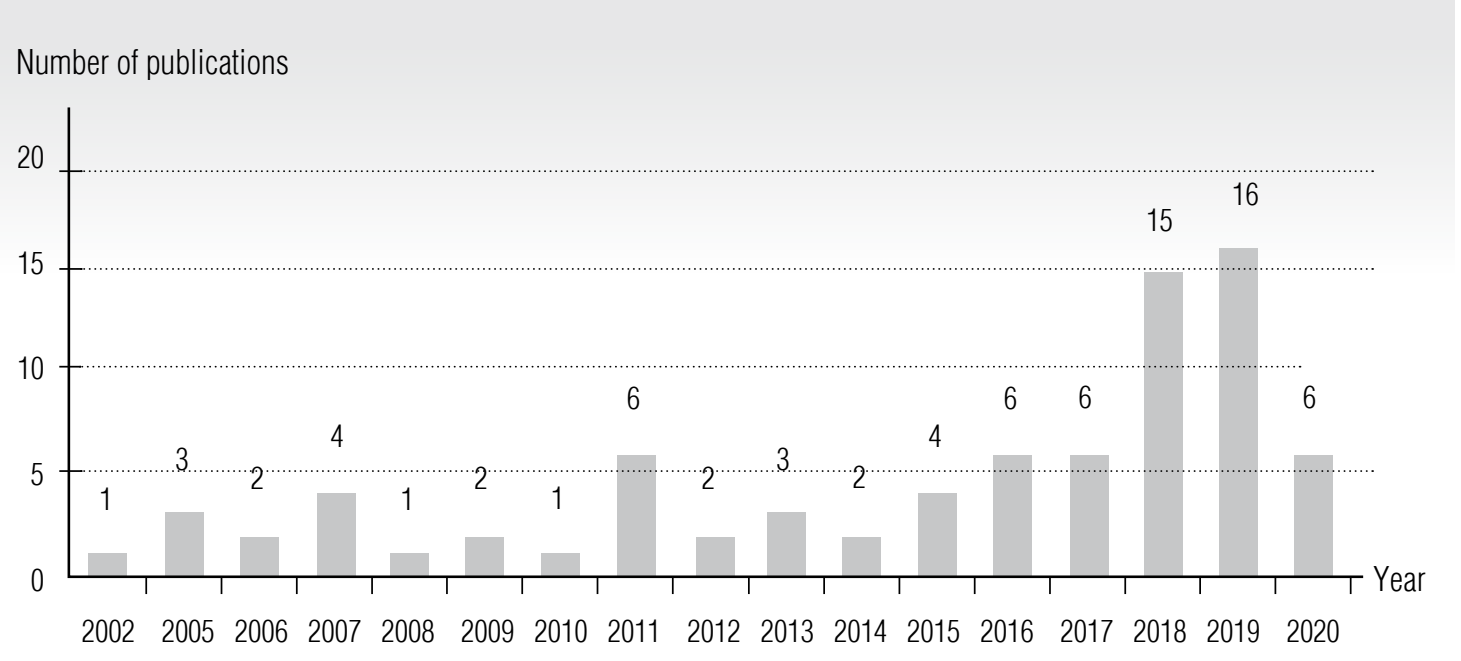

Fig. 1. The total number of publications on the problem of valuation of residential properties in the Scopus database

disputes, for determining the price of insurance by insurance companies, as well as making investment decisions.

In this regard, the problem of the accuracy and objectivity of estimating the value of residential properties becomes more and more urgent, including the issues of modeling the price of residential real estate, the study of factors affecting the cost, and the use of analytical methods of valuation.

In Russia, since the 1990s, a series of scientific works has been published devoted to the development of economic and mathematical methods of real estate valuation [2-4]. The classification proposed in [5] is fundamental for many studies. This paper presents the pricing in the housing market in Russia and highlights the pricing factors, which are divided by levels in relation to supply and demand. In [6-10], methods of neural network modeling were used to estimate the value of real estate.

The relevance of estimating the value of real estate is also noted in the works of several foreign authors [11-14].
Analysis of publications by foreign authors in the Scopus database for the period from 2000 to 2020 (Figure 1) also confirms the relevance of this issue, both for the Russian and foreign residential property markets.

As shown in Figure 1, interest in this issue has grown significantly in recent years. If in 2002 only one work was published, then 15 and 16 works, respectively, were devoted to estimating the value of real estate in 2018 and $2019^{1}$.

A significant share of the papers is devoted to the analysis and comparison of various methods for estimating the value of residential properties, both from a theoretical and practical point of view. Some authors focused their attention on the problem of estimating the impact of the value of residential properties on the mortgage crisis of 2008 in the context of mortgage lending [15]. The applicability of the concept of "sustainable real estate" in Poland and the issues of valuation of such real estate are considered in [16]. The authors of the work [17] studied the behavior of appraisers and buyers in the residential property market using a survey

${ }^{1}$ Scopus: http://scopus.com 
method. In studies [17-19], an expert system was developed to estimate the value of residential properties using decision support methods.

Many authors proposed their own models based on analytical methods for estimating the value of residential properties and tested them on real data. At the same time, the models had differences, both in terms of the methods used and the variables.

In [20], a multiple regression model was proposed that uses the tax rate, floors, number of bathrooms, total area, living space, number of garages, number of rooms, number of bedrooms, age of the house as independent variables. Work [21] estimated the influence of such factors as distance to the city center, availability of parking, ecology, floor on which the apartment is located, total area, noise, maintenance costs, availability of central heating, proximity to kindergartens and schools, wall material, age of the house, proximity to cultural and historical sites, the presence of a balcony or loggia.

A model for estimating the cost of apartments and residential properties, as a combination of an artificial neural network model and a geographic information system, based on data on the cost of residential properties in Albacete for 2002, was presented in [22]. The explanatory variables were the type of housing, location, age of the house, number of bedrooms, the presence of an elevator, a balcony, a parking space, a heating system, condition of the property and distance to the city center. In this paper, one of the most important variables was the distance to the central business center.

A significant number of publications consider the theoretical aspects of modeling the valuation of residential properties. They are devoted to the generalization of the models used, the analysis of the methods used, the purposes of the valuation and other charac- teristics of the spatial structure that determine the category of the proposed models. In work [23] models of real estate appraisal are analyzed depending on the purposes of the valuation (sale and purchase of property, mergers and acquisitions, taxation, mortgage lending). In [24], the models of real estate valuation are considered in the context of the methods used, which can be divided into two groups: traditional and advanced (analytical).

The traditional methods for estimating the value of residential properties [24-26] include the income method, the comparative method, the investment method and the cost method. Analytical methods include hedonic price models (HPM), artificial neural network (ANN), expert system (ES), fuzzy logic system (FLS), spatial analysis methods and Autoregressive Integrated Moving Average (ARIMA). At the same time, the ANN, ES and FLS methods are considered by the authors as estimation methods based on artificial intelligence technology.

In the study [27], the authors proposed a classification of analytical models for estimating the value of real estate and divided them into the following: models based on artificial intelligence methods, models based on a geographic information system and mixed models.

The purposes of this work are the following2:

$\downarrow$ to propose a spatial structure of residential property valuation models that allows classifying models from different points of view, namely: the estimated value, modeling methods, the number of valuation objects, modeling objectives, the modeling object, the type of object, the real estate market, the subject of the assessment and the level of modeling;

$\downarrow$ to provide a classification of factors affecting the cost of one square meter of residential property;

\footnotetext{
2 Preliminary results of the study were presented in the graduate work by Anastasia I. Poltorak performed at the HSE Faculty of Business and Management in 2019
} 
to develop a comprehensive model for estimating the value of residential properties in the secondary housing market in Moscow using the decision tree method to predict the level of comfort in housing and ordinal logistic regression to predict the estimation of the value of residential properties, using the results of the model for predicting the level of comfort in housing as input information;

$\downarrow$ to test the developed complex model on real data and estimate its predictive ability.

\section{Spatial structure of residential property valuation models}

The usually proposed classification of models assumes their division depending on the valuation methods used. Summarizing the above, Figure 2 represents the spatial structure of models for estimating the value of residential properties depending on various characteristics, which include:

$\checkmark$ estimated value (models for assessing market, residual, cadastral, investment, liquidation, book value);

$\checkmark$ modeling methods (models based on traditional and analytical methods);

$\checkmark$ number of objects (models of individual and mass appraisal of the value of residential properties);

$\checkmark$ the goals of modeling (models for prices forecasting, analyzing pricing factors, managing the value of residential properties, assessing the impact of external factors, taxation);

$\checkmark$ object of modeling (models for evaluating one square meter of residential property, residential property in general);

$\checkmark$ type of property (models for estimating residential buildings, apartments, rooms); $\checkmark$ type of market (models for evaluating residential properties in the primary and secondary markets);

$\checkmark$ subject of appraisal (models of appraisal of residential properties for a seller, buyer, investor);

$\checkmark$ level of modeling (models for evaluating residential properties at the regional level, federal level, at the level of a district, county, residential property).

\section{Analysis of the residential property market in Moscow}

According to Rosstat, among the subjects of the Russian Federation in 2019, the largest volumes of housing construction were carried out in the Moscow region and Moscow, where, respectively, $10.5 \%$ and $6.3 \%$ of the total area of housing commissioned in Russia ${ }^{3}$ was located. According to the Bank of Russia, the largest volume of loans in the total volume of housing loans in the Russian Federation was issued in Moscow (13.8\%) and in the Moscow region $(8.5 \%)$. At the same time, according to preliminary data, the real disposable cash income of the general population of Russia in 2019 increased by $1.0 \%$ compared to $2018^{4}$.

The weighted average interest rate on residential mortgage lending, according to the Bank of Russia, decreased from $9.87 \%$ in January to $9.00 \%$ in December 20195. In 2020, the downward trend in mortgage lending rates continued. In addition, in the period from April 17 to November 1, 2020, a preferential mortgage was introduced for the purchase of an apartment in new buildings with a rate of no more than $6.5 \%$, while the loan amount is limited (up to 8 million rubles in Moscow and the Moscow region) [28].

\footnotetext{
Russian Federal State Statistics Service: http://www.gks.ru

4 Central Bank of the Russian Federation: https://www.cbr.ru/

5 Central Bank of the Russian Federation: https://www.cbr.ru/
} 


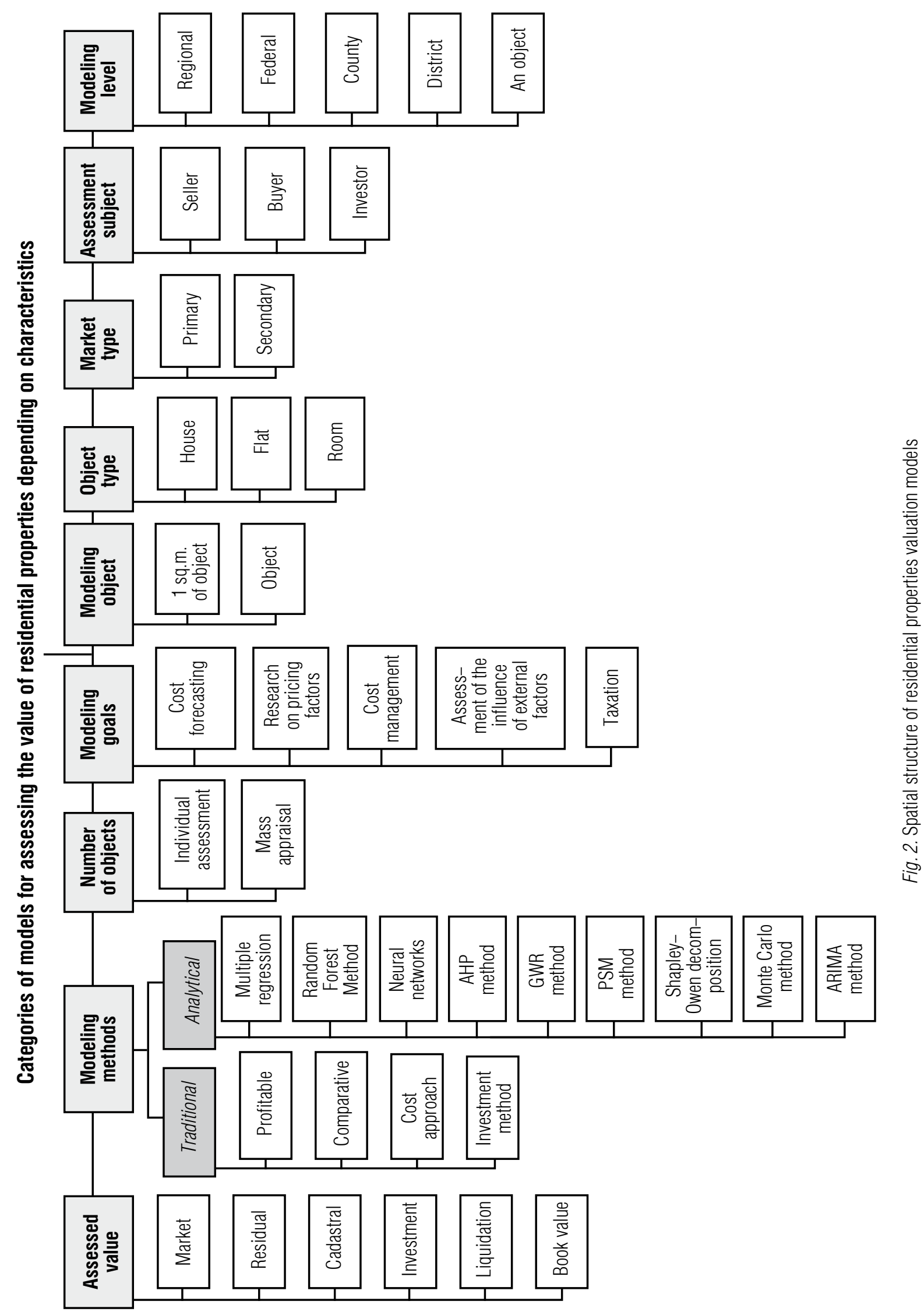


The residential property market in Moscow and the Moscow region is characterized by a wide variety of categories of properties, both in the primary and secondary markets. Depending on various factors, a certain price can be set for a particular property.

Among the significant variety of categories of residential properties, the majority in the market of Moscow and the Moscow region are residential properties located in apartment buildings. Therefore, to analyze the value of residential properties, it is appropriate to choose this category.

It should be noted that the cost of housing in Moscow and the Moscow region is influenced by various factors, which can be conditionally divided into environmental factors (exogenous) and internal factors (endogenous). The classification of factors affecting the cost of one square meter of an apartment is shown in Figure 3.

Among the exogenous factors, we can highlight the impact of factors of the world, country, and regional levels, and among the endogenous - factors that relate to the local level, and the factors of the given property itself.

The world-level factors affecting the cost of one square meter include the coronavirus pandemic, sanctions against Russia, changes in oil prices, exchange rates and other factors. Their influence is rather difficult to directly assess in value terms, but the indirect influence of these factors on the value of residential properties undoubtedly is felt. The impact of these factors is manifested, first, in a direct impact on the state of the country's economy, which leads to changes in the residential property sector.

Country-level factors include changes in mortgage lending rates, the introduction of escrow accounts, taxation, inflation and benefits. The influence of these factors can be directly determined. For example, according to the analysis carried out by the staff of the Institute of Economic Forecasting of the Russian Academy of Sciences, as a result of a decrease in the lending rate from 10 to $6.5 \%$, the value of the Housing Affordability Index (HAI) in the primary market will increase from $104.7 \%$ to $135.5 \%$ [29]. These measures were introduced by the state in order to support the construction sector and maintain the price level in the housing market at the expense of demand. The introduction of an escrow account mechanism, an increase in the VAT rate to $20 \%$ in 2019, and an increase in inflation (the level of which, according to the Central Bank of the Russian Federation, is expected to be in the range of 3.8-4.8\% at the end of 2020) have a significant impact on the value of residential properties $^{6}$.

Regional factors affecting the value of residential properties include population size, income level of the population, climatic conditions, renovation, supply and demand.

The value of a property is also influenced by internal factors that directly characterize the property itself and its location in relation to infrastructure. Among such factors at the local level, we can identify transport accessibility, infrastructure development, district/county, environmental situation, the presence of a parking space a guarded yard, a concierge, an elevator, etc. At the level of the building itself, we can highlight the factors that exert an influence, depending on whether this building is under construction or ready. Factors affecting the value of a secondary market property include year of construction, floor, total / living area, number of rooms, presence of a balcony, wall material, view from the window, ceiling height. The factors affecting the cost of the primary market building, in addition to the above factors, include the cost of construction, the stage of construction, the rating of the developer,

5 Central Bank of the Russian Federation: https://www.cbr.ru/ 


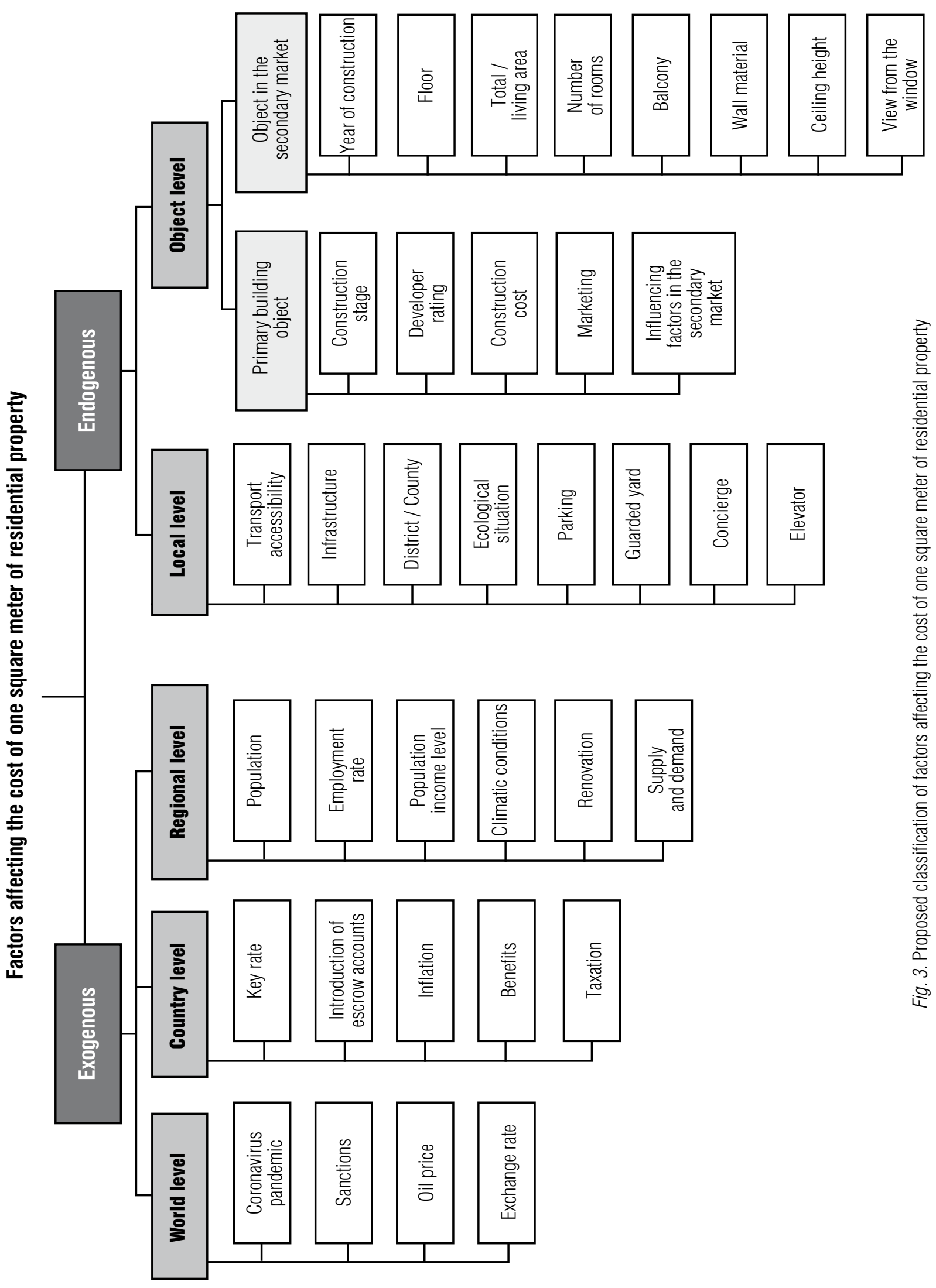


marketing. For example, the closer the delivery term, the more expensive the residential property is, and vice versa. When people buy residential properties at the construction stage, they pay special attention to the rating and experience of the developer, therefore, the cost of buildings with the same indicators from a more reliable developer is usually higher.

It should be noted that pricing in the primary and secondary residential property markets is significantly different. Therefore, the asset pricing model built for the primary market will not be relevant for the secondary market.

\section{A comprehensive model for predicting the value of residential properties in the secondary market}

The problem of predicting the value of real estate in the secondary housing market has been and remains relevant for several decades. A high-quality forecast helps to reduce risks, both for government and for realtors specializing in the purchase and sale of housing, as well as for ordinary citizens who buy or sell apartments. The developed complex model for predicting the value of residential properties in the secondary market includes two sub-models a model for predicting the level of comfort of housing based on local data, and a model for predicting the value of a unit of residential property based on building factors and input variables that are the result of predicting the comfort model of housing.

\subsection{Model for predicting the comfort level of residential properties in the secondary market in Moscow}

To predict the level of comfort in residential properties, a sample of 304 observations was formed, including 14 factors taken from the CIAN database ${ }^{7}$.

It is assumed that the dependent variable "comfort" can take three values: 1 - a minimum level of comfort; 2 - average level of comfort; 3 - a high level of housing comfort. The independent factors are: presence of an elevator, the year of construction, the district, the county, the presence of a garbage chute, presence of parking, "house for demolition," the distance from the metro, the type of house $(0-$ panel; 1 - brick; 2 - block; 3 - monolithic), presence of a concierge, number of floors, distance from the Moscow Ring Road, number of entrances, assessment of infrastructure $(1-$ minimally developed infrastructure; 2 - moderately developed infrastructure: there are shops and pharmacies, but no entertainment centers, medical and educational institutions; 3 - the most developed infrastructure).

The frequency distribution of the sample values according to the comfort level categories is as follows: the highest number of sample elements fell into the category of high comfort level -117 , the average comfort level category 101 , and the minimum comfort level category 86.

To predict the level of housing comfort in Moscow, 12 territorial-administrative districts values were randomly included in the sample and grouped into five enlarged districts according to the principle of the proximity of average housing prices (Table 1).

A new variable "district" was created, consisting of five combined districts and taking the following values:

$\uparrow$ Central;

$\downarrow$ North, East, South-West, North-West;

$\downarrow$ North-East, South-East, South;

$\downarrow$ Western;

\ Novomoskovsky, Zelenogradsky, Troitsky.

\footnotetext{
7 CIAN: https://www.cian.ru/
} 
Average values of house prices by area

\begin{tabular}{c|c|c|c|c} 
No & District & $\begin{array}{c}\text { Average price } \\
\text { in rubles }\end{array}$ & $\begin{array}{c}\text { Number } \\
\text { of observations }\end{array}$ & $\begin{array}{c}\text { Standard } \\
\text { deviation }\end{array}$ \\
\hline 1 & Central & 20634899.40 & 25 & 16110812.30 \\
\hline 2 & West & 13425600.00 & 25 & 6336071.39 \\
\hline 3 & East & 10571250.00 & 24 & 7849054.95 \\
\hline 4 & North & 10417986.20 & 25 & 6341765.62 \\
\hline 5 & South-West & 9797307.69 & 26 & 4014771.39 \\
\hline 6 & North-West & 9471791.92 & 24 & 4063054.40 \\
\hline 7 & South & 8560000.00 & 25 & 2340539.47 \\
\hline 8 & North-East & 8091280.00 & 25 & 2754360.66 \\
\hline 9 & South-East & 7535199.96 & 25 & 2385758.27 \\
\hline 10 & Novomoskovsky & 6437160.00 & 25 & 2232530.14 \\
\hline 11 & Zelenogradsky & 6124800.00 & 25 & 2243342.22 \\
\hline 12 & Troitsky & 4287666.67 & 30 & 1103601.26 \\
\hline Average total & & $\mathbf{9 6 1 2} \mathbf{9 1 1 . 8 2}$ & $\mathbf{3 0 4}$ & $\mathbf{4 8 1 4 6 3 8 . 5 1}$ \\
\hline
\end{tabular}

The histogram of the frequency distribution of the values of the "okrug" variable in the sample is shown in Figure 4.

As can be seen from the histogram, the largest number of values fell into category 2 , which is explained by the fact that this category covers four of the 12 territorial-administrative districts of Moscow at once.

To predict the level of comfort, the CRT decision tree method was used (tree depth , number of nodes -25 ). The significant variables include: "distance from the metro," "infrastructure," "distance from the Moscow Ring Road," "age of the house," "district," "number of levels of the house," "presence of an elevator," "type of house," "number of entrances," "presence of a garbage chute," "house for demolition," "availability of parking" and "presence of a concierge." 
As the analysis showed, buildings with the maximum level of comfort, first of all, are characterized by proximity to the metro the division into groups occurs at a level of more or less 16 minutes to the metro. Node 1 got 109 values from the sample corresponding to the maximum comfort level, which amounted to $66 \%$ of the values of node 1 . At the same time, node 2 received only 8 values from the sample with the maximum comfort level, which is only $5.8 \%$ of the values from node 2 .

Furthermore, there is a separation by distance from the Moscow Ring Road. If the property is near the metro, but outside the Moscow Ring Road, then, perhaps, its territorial location is not as attractive as buildings that are further from the metro, but closer to the center. At the same time, real estate that is not within walking distance of the metro is further divided according to the availability of parking, since their residents use their own vehicles. If there is a parking space, a greater number of node values belong to comfort groups 2 and 3 , while in the absence of a parking space, the object will most likely belong to comfort group 1 .

The classification of independent variables in terms of significance is shown in Figure 5. The share of correctly predicted values was $71.7 \%$. The predicted values of the comfort level and the resulting nodes are used to build a predictive model for the comfort of residential properties.

\subsection{Forecasting the cost of a unit of residential property in Moscow based on an ordinal logistic model}

An ordinal logistic regression model was used to predict the cost of a unit of residential property in the secondary market of Moscow. All residential property prices were grouped into six price categories (Table 2).
Table 2.

\section{Compliance with the category and price range of the apartment value}

\begin{tabular}{c|c}
$\begin{array}{c}\text { Category } \\
\text { number }\end{array}$ & $\begin{array}{c}\text { Price range } \\
\text { (RUB) }\end{array}$ \\
\hline 1 & less than 5 500 000 \\
\hline 2 & from 5 500 001 to 6450000 \\
\hline 3 & from 6 450 001 to 7500 000 \\
\hline 4 & from 7 500 001 to 8 950000 \\
\hline 5 & from 8 950001 to 13490000 \\
\hline 6 & more than 13490000 \\
\hline
\end{tabular}

Analysis of the constructed model coefficients showed that the following variables are significant: "total area" (totalarea), "ceiling height" (ceilingheight), "number of rooms" (rooms), "repairs," "balcony," "district" and "predicted comfort" ( Table 3).

The constructed model looks like:

$$
\begin{gathered}
P=\frac{1}{1+e^{-y}}, \\
y=0.133 \cdot \text { totalarea }+1.492 \cdot \text { ceilingheight }- \\
8.738 \cdot \text { rooms }-1.250 \cdot \text { repairs }- \\
-0.586 \cdot \text { balcony }+9.920 \cdot \text { district } 1+ \\
+5.608 \cdot \text { district } 2+4.959 \cdot \text { district } 3+ \\
+5.652 \cdot \text { district } 4-2.950 \cdot \text { comfort } 1- \\
-3.132 \cdot \text { comfort } 2,
\end{gathered}
$$

where district 1 - Central District;

district2 - union of four districts: North, East, South-West, North-West;

district 3 - the union of three districts: NorthEast, South-East, South;

district4 - Western District;

district5 - the union of three districts: Novomoskovsky, Zelenogradsky and Troitsky; 


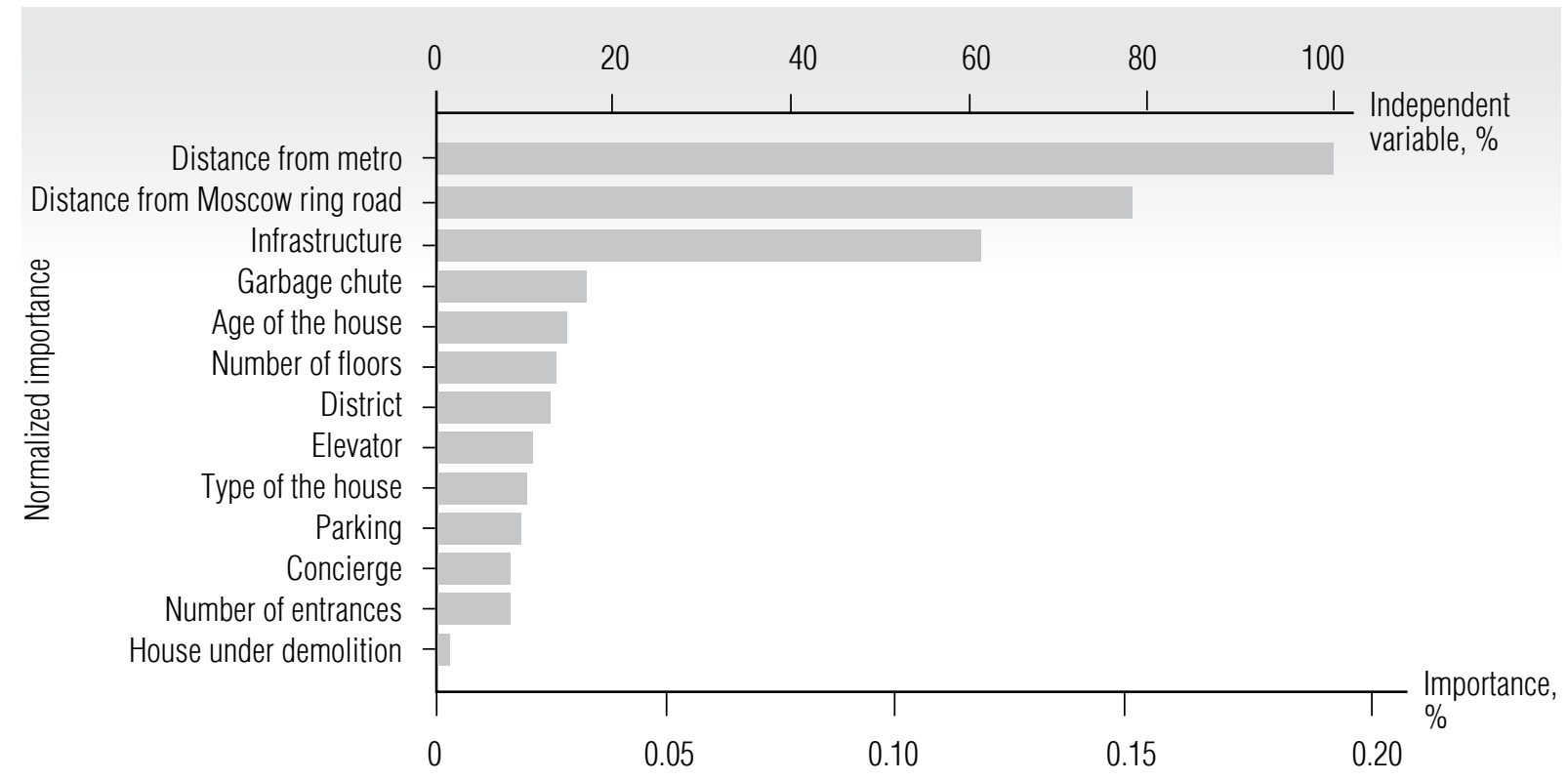

Fig. 5. Classification of independent variables by significance

\section{Ordinal logistic model of the cost of 1 sq. $m$ of residential property}

Table 3.

\begin{tabular}{c|c|c|c|c|c|c} 
No & Variable & Estimation & $\begin{array}{c}\text { Standard } \\
\text { error }\end{array}$ & Wald & $\begin{array}{c}\text { Degree } \\
\text { of freedom }\end{array}$ & Significance \\
\hline 1 & totalarea & 0.133 & 0.021 & 41.602 & 1 & 0.000 \\
\hline 2 & ceilingheight & 1.492 & 0.554 & 7.250 & 1 & 0.007 \\
\hline 3 & rooms & -8.738 & 0.374 & 546.982 & 1 & 0.000 \\
\hline 4 & repairs =0 & -1.250 & 0.289 & 18.73 & 1 & 0.000 \\
\hline 5 & repairs =1 & $0^{\text {a) }}$ & - & - & 0 & - \\
\hline 6 & balcony=0 & -0.586 & 0.307 & 3.652 & 1 & 0.056 \\
\hline 7 & balcony=1 & $0^{\text {a) }}$ & - & - & 0 & - \\
\hline 8 & district1 & 9.920 & 0.905 & 120.245 & 1 & 0.000 \\
\hline 9 & district2 & 5.608 & 0.507 & 122.387 & 1 & 0.000 \\
\hline 10 & district3 & 4.959 & 0.495 & 100.487 & 1 & 0.000 \\
\hline 11 & district4 & 5.652 & 0.654 & 74.702 & 1 & 0.000 \\
\hline 12 & district5 & $0^{\text {a) }}$ & - & - & 0 & - \\
\hline 13 & comfort1 & -2.950 & 0.413 & 51.124 & 1 & 0.000 \\
\hline 14 & comfort2 & -3.132 & 0.419 & 55.737 & 1 & 0.000 \\
\hline 15 & comfort3 & $0^{\text {a) }}$ & - & - & 0 & - \\
\hline
\end{tabular}

Connection function: logit

a) This parameter is set to zero because it is redundant 
comfort 1 - minimum housing comfort; comfort 2 - average housing comfort; comfort 3 - high housing comfort.

The variables "district" and "comfort" are dummy variables. In an equation, the number of dummy variables is always 1 less than the dummy variables themselves, since one of them is always the base variable. Thus, in this model, the variables district5 and comfort 3 are selected as basic variables.

The quality of the constructed model is evidenced by a decrease in the log likelihood with included variables by almost two times, high values of the pseudo R-square of Cox and Snell (0.849) and Nigelkirk (0.873), and the proportion of correctly predicted values (71\%).

To test the complex model we developed, a new sample of 30 apartments in the Moscow secondary market was collected, taken randomly from the CIAN database for 2019. Comparative data on approbation of the ordinal logistic model, including the actual and predicted category, as well as the average relative forecast error, are presented in Table 4.

As can be seen from table 4, the average forecast error was $10 \%$. This indicates a high predictive ability of the model. It should be noted that the model did not make gross errors: the values for only three observations were incorrectly predicted. At the same time, in the case of observation 8 , the actual price of the apartment is close to the lower border of the 6th price range and the model predicted falling into this price category. In the case of observation 24 , the actual price of the apartment is close to the upper border of the 4 th price range or to the lower border of the 5 th price range, and the model predicted entry to the 5th price range. The most serious forecast error was made in the case of observation 14, for which the actual price lies in the 5 th price range, and the forecast price category turned out to be the 6 th.
Thus, the approbation of the developed complex model for predicting the cost of a unit of residential property showed that the average relative forecast error does not exceed $10 \%$. At the same time, errors lie within neighboring price categories and take place only when the real price of residential property is close to the border of the price range. The complex model we developed makes it possible to estimate the price range in which the value of the property is located based on its initial characteristics.

\section{Conclusion}

Within the framework of this study, the existing Russian and foreign models and methods for predicting the value of residential properties have been analyzed. On this basis, the spatial structure of the models for estimating the value of residential properties is proposed, and the pricing factors influencing the value of residential properties in Moscow are identified, investigated and analyzed.

A model has been developed for predicting the comfort of residential properties based on a random sample of properties (apartments) in all administrative districts of Moscow based on CRT classification trees in which the dependent variable of the value of residential property was transformed into a categorical variable characterizing the price category. The predicted accuracy of the CRT classification tree method was $72 \%$. A complex model for predicting the cost of residential properties has been developed. It consists of two sub-models - a model for predicting the comfort of residential property and an ordinal logistic regression model for predicting the cost of a unit of residential property, including factors characterizing the building (apartment) and the predicted value of the level of comfort, which is the result of the model for predicting the comfort of residential objects. The ordinal 


\section{Forecast of the cost per unit of residential property in the secondary market of Moscow}

Table 4.

\begin{tabular}{|c|c|c|c|c|c|c|c|}
\hline No & $\begin{array}{l}\text { Predicted } \\
\text { category }\end{array}$ & $\begin{array}{c}\text { Predicted } \\
\text { probability of falling } \\
\text { into a category }\end{array}$ & $\begin{array}{c}\text { Price range } \\
\text { for a category, } \\
\text { RUB }\end{array}$ & $\begin{array}{c}\text { Actual value, } \\
\text { RUB }\end{array}$ & $\begin{array}{l}\text { Actual } \\
\text { category }\end{array}$ & $\begin{array}{l}\text { Category } \\
\text { entry } \\
\text { check }\end{array}$ & $\begin{array}{l}\text { Average } \\
\text { relative } \\
\text { forecast } \\
\text { error, } \%\end{array}$ \\
\hline 1 & 2 & 0.50 & $6450000-7500000$ & 6800000 & 2 & yes & \multirow{30}{*}{$10 \%$} \\
\hline 2 & 6 & 0.94 & $>13490000$ & 15200000 & 6 & yes & \\
\hline 3 & 4 & 0.52 & $7500000-8950000$ & 7800000 & 4 & yes & \\
\hline 4 & 5 & 0.65 & $8950000-13490000$ & 12500000 & 5 & yes & \\
\hline 5 & 4 & 0.46 & $7500000-8950000$ & 8200000 & 4 & yes & \\
\hline 6 & 3 & 0.58 & $6450000-7500000$ & 7000000 & 3 & yes & \\
\hline 7 & 3 & 0.58 & $6450000-7500000$ & 6650000 & 3 & yes & \\
\hline 8 & 6 & 0.89 & $>13490000$ & 13200000 & 5 & no & \\
\hline 9 & 2 & 0.54 & $6450000-7500000$ & 6500000 & 2 & yes & \\
\hline 10 & 6 & 1.00 & $>13490000$ & 22999000 & 6 & yes & \\
\hline 11 & 1 & 0.60 & $5500000-6450000$ & 6040000 & 1 & yes & \\
\hline 12 & 4 & 0.58 & $7500000-8950000$ & 8500000 & 4 & yes & \\
\hline 13 & 2 & 0.55 & $5500000-6450000$ & 5700000 & 2 & yes & \\
\hline 14 & 6 & 0.54 & $8950000-13490000$ & 9300000 & 5 & no & \\
\hline 15 & 4 & 0.59 & $7500000-8950000$ & 7950000 & 4 & yes & \\
\hline 16 & 2 & 0.55 & $5500000-6450000$ & 5700000 & 2 & yes & \\
\hline 17 & 2 & 0.54 & $5500000-6450000$ & 6200000 & 2 & yes & \\
\hline 18 & 5 & 0.58 & $8950000-13490000$ & 10300000 & 5 & yes & \\
\hline 19 & 1 & 0.90 & $5500000-6450000$ & 4950000 & 1 & yes & \\
\hline 20 & 2 & 0.47 & $5500000-6450000$ & 5900000 & 2 & yes & \\
\hline 21 & 2 & 0.53 & $5500000-6450000$ & 6800000 & 2 & yes & \\
\hline 22 & 4 & 0.53 & $7500000-8950000$ & 8750000 & 4 & yes & \\
\hline 23 & 2 & 0.55 & $5500000-6450000$ & 5200000 & 2 & yes & \\
\hline 24 & 5 & 0.64 & $7500000-8950000$ & 8700000 & 4 & no & \\
\hline 25 & 3 & 0.56 & $6450000-7500000$ & 7350000 & 3 & yes & \\
\hline 26 & 2 & 0.50 & $5500000-6450000$ & 6100000 & 2 & yes & \\
\hline 27 & 4 & 0.55 & $7500000-8950000$ & 7800000 & 4 & yes & \\
\hline 28 & 2 & 0.43 & $5500000-6450000$ & 5850000 & 2 & yes & \\
\hline 29 & 2 & 0.49 & $5500000-6450000$ & 5850000 & 2 & yes & \\
\hline 30 & 5 & 0.62 & $8950000-13490000$ & 11300000 & 5 & yes & \\
\hline
\end{tabular}


logistic regression model showed a predictive accuracy of $71 \%$. The comprehensive model we developed was also tested on real data on the cost of residential properties in the secondary market of Moscow for 2019. The relative error in the forecast of the price category of the value of residential properties was $10 \%$.

\section{References}

1. Housing code of the Russian Federation. Federal law No 188-FZ of 29 December 2004 (ed. from 31 July 2020). Available at: http://www.consultant.ru/document/cons_doc_LAW_51057/ (accessed 05 August 2020) (in Russian).

2. Gribovsky S.V., Sivets S.A. (2008) Mathematical methods for estimating the value of real estate. Moscow: Finance and Statistics (in Russian).

3. Gribovsky S.V., Fedotova M.A., Sternik G.M., Zhitkov D.B. (2005) Economic and mathematical models of real estate valuation. Finance and Credit, no 3 (171), pp. 24-43 (in Russian).

4. Sigel E. (2008) Practical business statistics. Moscow: Williams (in Russian).

5. Sternik G.M., Sternik S.G. (2009) Real estate market analysis for professionals. Moscow: Economics (in Russian).

6. Molchanova M.Yu., Pechenkina A.V. (2015) Application of the scenario method in predicting the situation on the housing market in Perm. Perm University Herald, no 1 (24), pp. 79-88 (in Russian).

7. Pechenkina A.V. (2010) Using a multi-level factor model in predicting the situation on the regional real estate market (on the example of the Perm region). Property Relations in the Russian Federation, no 11 (110), pp. 57-72 (in Russian).

8. Khabibrahmanova R.R., Khabibrahmanov R.R. (2015) Modeling the dynamics of price changes in the housing market in Kazan. Management of Economic Systems. Scientific Electronic Journal, no 4 (76), p. 57 (in Russian).

9. Alekseev A.O., Kharitonov V.A., Yasnitsky V.L. (2018) Developing the concept of complex neural network modeling of mass assessment processes and scenario forecasting of residential real estate market value. Proceedings of Universities. Investment. Construction. Real Estate, vol. 8, no 1 (24), pp. 11-22 (in Russian).

10. Yasnitsky L.N., Yasnitsky V.L. (2017) Development and application of complex neural network models for mass estimation and forecasting of the cost of residential properties on the example of real estate markets in Ekaterinburg and Perm. Property Relations in the Russian Federation, vol. 186, no 3, pp. 68-84 (in Russian).

11. Hefferan M.J., Boyd T. (2010) Property taxation and mass appraisal valuations in Australia adapting to a new environment. Property Management, vol. 28, no 3, pp. 149-162.

DOI: $10.1108 / 02637471011051291$.

12. Gonzalez M.A.S., Formoso C.T. (2006) Mass appraisal with genetic fuzzy rule-based systems. Property Management, vol. 24, no 1, pp. 20-30. DOI: 10.1108/02637470610643092.

13. Davis P., McCluskey W., Grissom T.V., McCord M. (2012) An empirical analysis of simplified valuation approaches for residential property tax purposes. Property Management, vol. 30, no 3, pp. 232-254. DOI: 10.1108/02637471211233774.

14. Guan J., Shi D., Zurada J.M., Levitan A.S. (2014) Analyzing massive data sets: An adaptive fuzzy neural approach for prediction with a real estate illustration. Journal of Organizational Computing and Electronic Commerce, vol. 24, no 1, pp. 94-112. DOI: 10.1080/10919392.2014.866505.

15. Bowcock P. (2015) A discussion paper on valuations for mortgage and the level of house prices. International Journal of Housing Markets and Analysis, vol. 8, no 1, pp. 27-35.

DOI: 10.1108/IJHMA-07-2014-0024. 
16. Kucharska-Stasiak E., Olbińska K. (2018) Reflecting sustainability in property valuation-defining the problem. Real Estate Management and Valuation, vol. 26, no 2, pp. 60-70. DOI: $10.2478 /$ remav-2018-0016.

17. Naderi I., Sharbatoghlie A., Vafaeimehr A. (2012) Housing valuation model: An investigation of residential properties in Tehran. International Journal of Housing Markets and Analysis, vol. 5, no 1, pp. 20-40. DOI: 10.1108/17538271211206644.

18. Kucharska-Stasiak E., Źróbek S., Cellmer R. (2018) Forms and effectiveness of the client's influence on the market value of property - Case study. Real Estate Management and Valuation, vol. 26, no 3, pp. 82-92. DOI: 10.2478/remav-2018-0027.

19. Kilpatrick J. (2011) Expert systems and mass appraisal. Journal of Property Investment and Finance, vol. 29, no 4, pp. 529-550. DOI: 10.1108/14635781111150385.

20. Narula S.C., Wellington J.F., Lewis S.A. (2012) Valuating residential real estate using parametric programming. European Journal of Operational Research, vol. 217, no 1, pp. 120-128. DOI: 10.1016/j.ejor.2011.08.014.

21. Ferlan N., Bastic M., Psunder I. (2017) Influential factors on the market value of residential properties. Engineering Economics, vol. 28, no 2, pp. 135-144. DOI: 10.5755/j01.ee.28.2.13777.

22. García N., Gámez M., Alfaro E. (2008) ANN+GIS: An automated system for property valuation. Neurocomputing. vol. 71, no 4-6, pp. 733-742. DOI: 10.1016/j.neucom.2007.07.031.

23. Shapiro E., Mackmin D., Sams G. (2012) Modern methods of valuation. London: Estates Gazette. DOI: $10.4324 / 9780080971179$.

24. Pagourtzi E., Assimakopoulos V., Hatzichristos T., French N. (2003) Real estate appraisal: a review of valuation methods. Journal of Property Investment and Finance, vol. 21, no 4, pp. 383-401. DOI: $10.1108 / 14635780310483656$.

25. Tao C. (2010) On the use of analytic network process for modeling housing prices: a Chongqing perspective. Doctoral dissertation. Hong Kong: City University of Hong Kong.

26. Özkan G., Yalpır Ş., Uygunol O. (2007) An investigation on the price estimation of residable real estates by using artificial neural network and regression methods. Proceedings of the 12th Applied Stochastic Models and Data Analysis International conference (ASMDA), Chania, Crete, Greece, 29 May1 June 2007, pp. 1-8.

27. Wang D., Li V.J. (2019) Mass appraisal models of real estate in the 21st Century: A Systematic literature review. Sustainability, vol. 24, no 11, pp. 1-14. DOI: 10.3390/su11247006.

28. Government of the Russian Federation (2020) About approval of rules of compensation to credit and other organizations of the lost income on the housing (mortgage) credits (loans) issued to citizens of the Russian Federation in 2020. Decree of the Government of the Russian Federation No 566 of 23 April 2020. Available at: http://government.ru/docs/39558/ (accessed 18 July 2020) (in Russian).

29. Nozdrina N.N., Minchenko M.M. (2020) Analysis of changes in housing affordability in the light of the introduction of a preferential mortgage lending rate for 2020. Available at: https://ecfor.ru/ publication/dostupnosti-zhilya-stavka-ipotechnogo-kreditovaniya/ (accessed 18 July 2020) (in Russian).

\section{About the authors}

\section{Tatiana K. Bogdanova}

Cand. Sci. (Econ.);

Associate Professor, Department of Business Informatics, Graduate School of Business,

National Research University Higher School of Economics,

20, Myasnitskaya Street, Moscow 101000, Russia;

E-mail: tanbog@hse.ru

ORCID: 0000-0002-0018-2946 


\section{Albina R. Kamalova}

Doctoral Student, Department of Business Informatics, Graduate School of Business, National Research University Higher School of Economics,

20, Myasnitskaya Street, Moscow 101000, Russia;

E-mail: akamalova@hse.ru

\section{Tatiana K. Kravchenko}

Dr. Sci. (Econ.);

Professor, Department of Business Informatics, Graduate School of Business, National Research University Higher School of Economics,

20, Myasnitskaya Street, Moscow 101000, Russia;

E-mail: tkravchenko@hse.ru

ORCID: 0000-0002-6479-6250

\section{Anastasia I. Poltorak}

Leading Analyst, Seldon 2 LLC,

24 build. 1, Radio Street, Moscow 105005, Russia;

E-mail: poltoraknastya@gmail.com 